\title{
Photoperiod and Temperature Effects on Growth and Carbohydrate Storage in Southern Highbush Blueberry Interspecific Hybrid
}

\author{
Timothy M. Spann, Jeffrey G. Williamson, and Rebecca L. Darnell \\ Horticultural Sciences Department, University of Florida, Gainesville, FL 32611
}

\begin{abstract}
ADDITIONAL INDEX wORDs. daylength, flower bud initiation, flower development
ABSTRACT. Experiments were conducted with 'Misty'southern highbush blueberry (Vaccinium corymbosum L. interspecific hybrid) to test the effects of high temperature on flower bud initiation and carbohydrate accumulation and partitioning. Plants were grown under inductive short days (SDs = 8 hour photoperiod) or noninductive SDs with night interrupt (SD$\mathrm{NI}=8$ hour photoperiod +1 hour night interrupt), at either 21 or $28{ }^{\circ} \mathrm{C}$ for either 4 or 8 weeks. Flower bud initiation occurred only in the inductive SD treatments and was significantly reduced at $28{ }^{\circ} \mathrm{C}$ compared with $21^{\circ} \mathrm{C}$. The number of flower buds initiated was not significantly different between 4 - and 8-week durations within the inductive $\mathrm{SD}, 21^{\circ} \mathrm{C}$ treatment. However, floral differentiation appeared to be incomplete in the 4-week duration buds and bloom was delayed and reduced. Although plant carbohydrate status was not associated with differences in flower bud initiation between SD and SD-NI treatments, within SD plants, decreased flower bud initiation at high temperature was correlated with decreased whole-plant carbohydrate concentration. These data indicate that flower bud initiation in southern highbush blueberry is a SD/long night phytochrome-mediated response, and plant carbohydrate status plays little, if any, role in regulating initiation under these experimental conditions.
\end{abstract}

Temperature can modify the photoperiod requirement for flower bud initiation in many photoperiodic plants. In fact, the generalization has been made that it is rare to find a plant in which photoperiodic responses are completely independent of temperature (Rees, 1987). For example, in short-day strawberry (Fragaria $\times$ ananassa Duch.), maximum flower bud initiation occurs at photoperiods $<12$ $\mathrm{h}$ and 15 to $20^{\circ} \mathrm{C}$ (Sonsteby, 1997). At temperatures $<10$ to $15^{\circ} \mathrm{C}$, strawberry will initiate flowers at longer photoperiods, and some cultivars will flower under 24 hour photoperiods if temperatures are $<10{ }^{\circ} \mathrm{C}$. On the other hand, high temperatures can reduce or inhibit flower bud initiation even under inductive photoperiods (Darrow, 1936; Hartmann, 1947; Heide, 1977). The number of inductive cycles required for flower bud initiation in strawberry is also positively correlated with temperature, increasing as temperature increases (Ito and Saito, 1962; Sonsteby, 1997).

Flower bud initiation in response to photoperiod is well documented in blueberry (Aalders and Hall, 1964; Darnell, 1991; Hall and Ludwig, 1961; Hall et al., 1970; Phatak and Austin, 1990; Spann et al., 2003). However, information on the interaction of temperature and photoperiod on blueberry flower bud initiation is limited. Hall and Ludwig (1961) found that flower bud initiation in lowbush blueberry (Vaccinium angustifolium Ait.) occurred at both 11- and 13-h photoperiods with temperatures of either 10 or $21^{\circ} \mathrm{C}$. Under 15 -h photoperiods, no initiation took place at either temperature.

Research on the duration of exposure to inductive photoperiods for normal flower bud initiation in blueberry is also limited. Lowbush blueberry plants grown under 2, 3, or 4 weeks of short days (SDs) (8-h photoperiod) and constant $18^{\circ} \mathrm{C}$ produced flowers, but the inflorescence internodes were elongated and bracts subtending individual flowers were larger than normally observed (Hall and Ludwig, 1961). Plants exposed to SDs for 5 or 6 weeks produced normal flowers, but the 5-week treatment produced fewer flowers than the 6-week treatment, suggesting that photoperiod duration

Received for publication 8 Jan. 2003. Accepted for publication 3 Nov. 2003. Florida Agricultural Experiment Station journal series R-09866. affects flower bud number. Phatak and Austin (1990) demonstrated that 6 weeks of inductive SDs are required for normal flower bud formation in rabbiteye blueberry (Vaccinium ashei Reade).

Although flower bud initiation in photoperiodic plants appears to be primarily phytochrome mediated (Vince-Prue, 1986), evidence indicates that plant carbohydrate status also affects initiation. Partitioning of translocated assimilates to stem node tissue in rabbiteye blueberry increases under SD compared with long day conditions (Darnell, 1991). This increase occurs as early as 2 weeks into the short photoperiod, before completion of the 5- to 6-week inductive cycle required for optimum initiation in blueberry. Increased carbohydrate allocation to nodes has also been suggested as a prerequisite for floral initiation in other photoperiodic plants (Bernier et al., 1993; Bodson, 1977).

Little is known about the effects of high temperature on the photoperiodic cycle or the number of cycles required for flower bud initiation in blueberry. In the present study, we tested the hypothesis that high temperature did not interact with photoperiod in the flower bud initiation process in blueberry. The specific objectives were to determine the effect of high temperature under inductive and noninductive photoperiods on 1) flower bud number under two photoperiodic durations ( 4 and 8 weeks) and 2) the correlation between flower bud initiation and reserve carbohydrate levels.

\section{Materials and Methods}

On 27 Nov. 2000, 110 one-year-old bareroot southern highbush blueberry plants, cv. Misty, were obtained from a commercial blueberry nursery. Plants were potted into $5 \mathrm{~L}$ containers using pine bark medium and placed outside in full sun. No frost protection was provided and plants were allowed to enter dormancy. On 3 Jan. 2001, the plants were placed randomly into a walk-in cooler and chilled at $7{ }^{\circ} \mathrm{C}$ for $336 \mathrm{~h}$ (14 d). On 17 Jan. 2001, plants were moved to a greenhouse for forcing at $21 / 18^{\circ} \mathrm{C}$ day/night and average photosynthetic photon flux $(P P F)$ of $1000 \mu \mathrm{mol} \cdot \mathrm{m}^{-2} \cdot \mathrm{s}^{-1}$. All flower buds were removed to promote vegetative growth. Daylength extension to $16 \mathrm{~h}$ (natural daylength $10 \mathrm{~h}$ and $30 \mathrm{~min}$ ) was provided 
Table 1. Treatment designations and descriptions.

\begin{tabular}{lccc}
\hline Treatment & Photoperiod $^{z}$ & $\begin{array}{c}\text { Temp } \\
\left({ }^{\circ} \mathrm{C}\right)\end{array}$ & $\begin{array}{c}\text { Photoperiod } \\
\text { duration } \\
\text { (weeks) }\end{array}$ \\
\hline SD-21-4 & SD & 21 & 4 \\
SD-28-4 & SD & 28 & 4 \\
SD-21-8 & SD & 21 & 8 \\
SD-28-8 & SD & 28 & 8 \\
SD-NI-21-4 & SD-NI & 21 & 4 \\
SD-NI-28-4 & SD-NI & 28 & 4 \\
SD-NI-21-8 & SD-NI & 21 & 8 \\
SD-NI-28-8 & SD-NI & 28 & 8
\end{tabular}

${ }^{2} \mathrm{SD}=$ short-day $(8-\mathrm{h})$ photoperiod; SD-NI = short-day $(8-\mathrm{h})+1$-h night interrupt in the middle of the dark cycle. $P P F$ averaged $530 \mu \mathrm{mol} \cdot \mathrm{m}^{-2} \cdot \mathrm{s}^{-1}$ during the day for both photoperiods and $114 \mu \mathrm{mol} \cdot \mathrm{m}^{-2} \cdot \mathrm{s}^{-1}$ during the night interrupt.

by a combination of $100 \mathrm{~W}$ incandescent light bulbs (spaced $\approx 1.2 \times$ $0.6 \mathrm{~m}$ apart) and 40W fluorescent lights (1.2-m twin-bulb fixtures positioned end-to-end) suspended $0.3 \mathrm{~m}$ above the plant canopy, providing $75 \mu \mathrm{mol} \cdot \mathrm{m}^{-2} \cdot \mathrm{s}^{-1} P P F$ at the top of the plant canopy. Plants were watered as needed and fertilized weekly with $500 \mathrm{~mL}$ of $20 \mathrm{~N}-8.7 \mathrm{P}-16.6 \mathrm{~K}$ water soluble fertilizer (Scotts-Sierra Horticultural Products Co., Marysville, Ohio) at $200 \mathrm{mg} \mathrm{N} / \mathrm{L}$.

On 19 Mar. 2001, total cane length (including all lateral canes) was measured and plants were blocked into 10 replications of eight plants each according to total cane length. One plant from each replication was randomly assigned to one of eight treatments. The treatments were a factorial arrangement of two photoperiods, two temperatures, and two durations: inductive SDs (8-h photoperiod) or noninductive SDs + night interrupt (SD-NI) (8-h photoperiod with $1 \mathrm{~h}$ night interrupt in the middle of the dark cycle), constant temperatures of 21 or $28{ }^{\circ} \mathrm{C}$, and 4 - or 8-week photoperiod durations (Table 1). The design was a randomized complete block with 10 single plant replications.

Plants in each treatment were placed in growth chambers (Conviron model E15; Controlled Environments, Ltd., Winnipeg, Manitoba, Canada) set to maintain the treatment conditions. PPF averaged $530 \mu \mathrm{mol} \cdot \mathrm{m}^{-2} \cdot \mathrm{s}^{-1}$ with a red to far red ratio of $4: 1$ during the day, and $114 \mu \mathrm{mol} \cdot \mathrm{m}^{-2} \cdot \mathrm{s}^{-1}$ with a red to far red ratio of 3 : 1 during the night interrupt. Plants were watered as needed, but fertilizer was withheld during the treatment period.

On 19 Apr. and 18 May 2001, plants in the 4- and 8-week treatments, respectively, were removed from the growth chambers. Four plants from each treatment were randomly selected for carbohydrate analysis. The remaining plants in each treatment were placed under 8 weeks of long days (16-h photoperiod), $P P F \approx 250 \mu \mathrm{mol} \cdot \mathrm{m}^{-2} \cdot \mathrm{s}^{-1}$, a red:far red ratio of $3.3: 1$, and constant temperature of $21^{\circ} \mathrm{C}$ for post-treatment observation. These conditions were achieved in a modified walk-in cooler equipped with incandescent and highoutput fluorescent lights. Fertilization was resumed on a weekly basis as previously described.

Terminal bud formation, if it occurred, was recorded as the number of days from the beginning of the treatment period. Total cane length was recorded at the beginning of the experiment and every 2 weeks during the 8-week post-treatment observation period. Total cane length measurements were not taken during the photoperiod/temperature treatments. Total number of flower buds were counted weekly for 8 weeks during the post-treatment observation period.

$\mathrm{NetCO}_{2}$ assimilation was measured twice during the photoperiod/ temperature treatments using a Parkinson leaf chamber (broad leaf model) attached to a portable leaf chamber analyzer and air supply unit (Analytical DevelopmentCo., Hoddesdon, England). Measurements were taken at 2 and 6 weeks, therefore, data from plants in the 4-week treatments were only included in the week 2 measurements. Net $\mathrm{CO}_{2}$ assimilation data were collected from recently expanded, mature leaves at least one hour after the beginning of the light period (45 min for the night interrupt) to ensure the photosynthetic rate was equilibrated for the given conditions.

Whole-plant fresh weights, including roots washed clean of potting media, were recorded for the plants selected for carbohydrate analysis. Plants were then separated into leaves, old canes, new canes (growth produced since forcing), and roots, and fresh weight was recorded for each tissue. Tissues were dried to a constant weight at $70{ }^{\circ} \mathrm{C}$, dry weight was then recorded for each tissue. Dried tissues were ground to pass a 20 -mesh $(1.27-\mathrm{mm})$ screen. Soluble sugars were extracted by shaking a 50-mg sample of tissue in $2 \mathrm{~mL} 80 \%$ ethanol for $20 \mathrm{~min}$. Samples were centrifuged, the supernatant decanted, and the tissue reextracted twice. The supernatants were combined and total volume determined. Pigment was removed from the tissue extracts by adding $35 \mathrm{mg}$ activated charcoal followed by $25 \mathrm{mg}$ polyvinylpolypyrrolidone. Soluble sugars were assayed using the phenol-sulphuric acid assay (Dubois, 1956; Buysse and Merckx, 1993) as modified by Chaplin and Kennedy (1994). An external ${ }^{14} \mathrm{C}$ sucrose standard was used to determine percent recovery.

Tissue starch concentration was determined by suspending the insoluble fraction from the $80 \%$ ethanol extraction in $2 \mathrm{~mL} 0.2 \mathrm{~N}$ $\mathrm{KOH}$ and boiling for $30 \mathrm{~min}$. After cooling to room temperature, $\mathrm{pH}$ was adjusted to 4.5 by adding $1 \mathrm{~mL} 1 \mathrm{M}$ acetic acid. Starch was digested by adding 118 units $(1 \mathrm{~mL})$ Rhizopus amyloglucosidase and 4 units $(1 \mathrm{~mL})$ barley malt $\alpha$-amylase (Sigma Chemical Co., St. Louis, Mo.), each dissolved in $0.2 \mathrm{M}$ calcium acetate buffer ( $\mathrm{pH}$ 4.5). Samples were incubated for $24 \mathrm{~h}$ at $37^{\circ} \mathrm{C}$. After incubation, samples were centrifuged, the supernatant decanted and volume recorded. The pellets were digested a second time to determine the efficiency of the first digestion. Pigment was removed from the samples by adding $25 \mathrm{mg}$ activated charcoal. The glucose liberated during each digestion was assayed using the phenol-sulfuric acid assay described earlier. The assay results from each digestion were summed for analysis. An external ${ }^{14} \mathrm{C}$ sucrose standard was used to determine percent recovery.

Total cane length data were analyzed as a factorial by analysis of variance (SAS, PROC GLM; SAS Institute, Cary, N.C.) using pre-treatment values as a covariant due to variation of plant size within treatments. Flower bud and carbohydrate data were analyzed as a factorial by analysis of variance and mean separation, using least square means (SAS, PDIFF).

\section{Results}

Total cane length was similar for all plants before placing them in the photoperiod/temperature treatments, averaging $180 \mathrm{~cm}$. At the end of the photoperiod/temperature treatments, total cane length was greater $(P<0.01)$ for the SD-NI plants compared with the SD plants under both temperatures (239 vs. $202 \mathrm{~cm}$, respectively), and greater $(P=0.01)$ for the 8-week compared with the 4-week photoperiod duration plants (233 vs. $209 \mathrm{~cm}$, respectively), again regardless of temperature. Temperature was nonsignificant and there were no significant interactions on total cane length.

Terminal bud formation occurred during week 5 of SD-21-8 and week 6 of SD-28-8 treatments, and during week 2 of the posttreatment observation period in the SD-21-4 treatment. Terminal 
Table 2. Photoperiod, temperature, and photoperiod duration effects on flower bud number in 'Misty' southern highbush blueberry $(n=4)$.

\begin{tabular}{lccccc}
\hline & \multicolumn{4}{c}{ Flower bud no./plant ${ }^{z}$} \\
\cline { 2 - 3 } \cline { 5 - 6 } Photoperiod & \multicolumn{2}{c}{$2{ }^{\circ} \mathrm{C}$} & & \multicolumn{2}{c}{$28^{\circ} \mathrm{C}$} \\
\cline { 2 - 3 } \cline { 5 - 6 } SD & $43.7 \mathrm{a} \mathrm{A}^{\mathrm{w}}$ & $32.4 \mathrm{ab} \mathrm{A}$ & & $0.0 \mathrm{c} \mathrm{C}$ & $17.2 \mathrm{bc} \mathrm{B}$ \\
SD-NI & $0.6 \mathrm{c} \mathrm{C}$ & $0.5 \mathrm{c} \mathrm{C}$ & & $0.0 \mathrm{c} \mathrm{C}$ & $0.0 \mathrm{c} \mathrm{C}$ \\
\hline
\end{tabular}

${ }^{\mathrm{z}}$ After completion of the photoperiod/temperature treatments, plants were placed in long days $(16 \mathrm{~h}), 21^{\circ} \mathrm{C}$, and $P P F \approx 250 \mu \mathrm{mol} \cdot \mathrm{m}^{-2 \cdot \mathrm{s}^{-1}}$ for 8 weeks before final determination of flower bud number.

y 4 = 4-week photoperiod duration; $8=8$-week photoperiod duration. ${ }^{\mathrm{x} D}=$ short-day $(8-\mathrm{h})$ photoperiod; $\mathrm{SD}-\mathrm{NI}=$ short-day $(8-\mathrm{h})+1$-h night interrupt in the middle of the dark cycle. $P P F$ averaged $530 \mu \mathrm{mol} \cdot \mathrm{m}^{-2} \cdot \mathrm{s}^{-1}$ during the day for both photoperiods and $114 \mu \mathrm{mol} \cdot \mathrm{m}^{-2} \cdot \mathrm{s}^{-1}$ during the night interrupt.

wLetters indicate mean separation within rows and columns by Duncan's multiple range test, $P \leq 0.05$ (lower case) or $P<0.10$ (upper case).

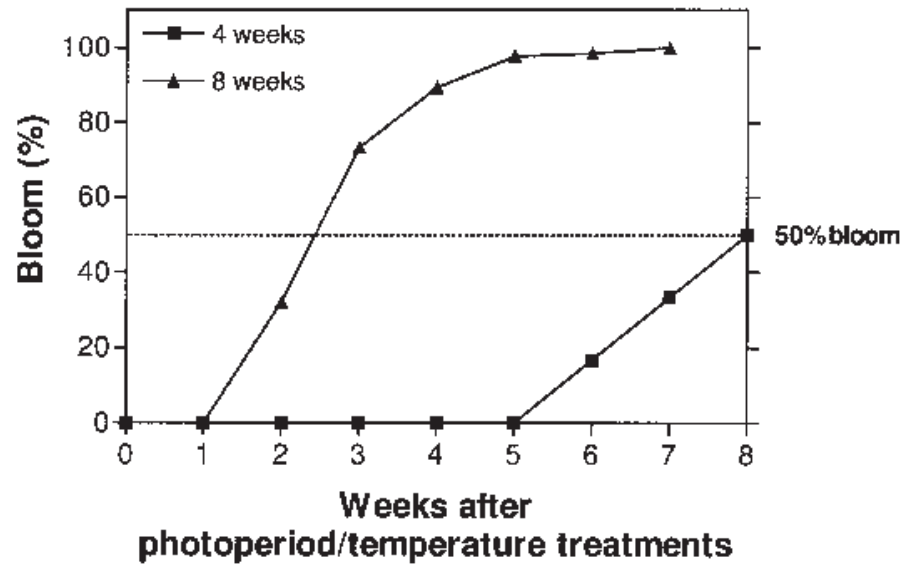

Fig. 1. Cumulative percent bloom for 'Misty' southern highbush blueberry exposed to short days ( 8 -h photoperiod, $P P F \approx 530 \mu \mathrm{mol} \cdot \mathrm{m}^{-2} \cdot \mathrm{s}^{-1}$ ) and $21^{\circ} \mathrm{C}$ for 4 or 8 weeks, then placed under 8 weeks of long days $(16 \mathrm{~h}), 21^{\circ} \mathrm{C}$, and $P P F \approx 250$ $\mu \mathrm{mol} \cdot \mathrm{m}^{-2} \cdot \mathrm{s}^{-1}(\mathrm{n}=6)$.

bud formation did not occur in the SD-28-4 treatment or any of the SD-NI treatments.

Flower bud number was greatest in the SD plants at $21^{\circ} \mathrm{C}(32-44$ buds/plant) compared with the SD-NI and the SD-28-4 treatments, in which flower bud initiation was almost completely inhibited (Table 2). Plants in the SD-28-8 treatment formed an average of 17 flower buds. Fifty percent bloom occurred between weeks 2 and 3 of the post-treatment observation period for the SD-21-8 treatment, but did not occur until week 8 for the SD21-4 treatment (Fig. 1). Flower buds formed in the SD-28-8 treatment plants did not bloom during the post-treatment observation period, nor was any swelling or enlargement observed in these flower buds.

Net $\mathrm{CO}_{2}$ assimilation rate was greater in the $21{ }^{\circ} \mathrm{C}$ treatments $\left(11.0+0.2 \mu \mathrm{mol} \cdot \mathrm{m}^{-2 \cdot} \cdot \mathrm{s}^{-1}\right)$ compared with the $28^{\circ} \mathrm{C}$ treatments $(6.1$ $\left.+0.1 \mu \mathrm{mol} \cdot \mathrm{m}^{-2} \cdot \mathrm{s}^{-1}\right)$ for both the SD and SD-NI photoperiods on 4 Apr. 2001, with no interaction between photoperiod and temperature. However, assimilation rates on 1 May 2001 were similar among all treatments, averaging $8.0+0.6 \mu \mathrm{mol} \cdot \mathrm{m}^{-2} \cdot \mathrm{s}^{-1}$.

At the end of the photoperiod/temperature treatment period, dry weights of leaves, old canes, new canes, and whole plants were greater for the SD-NI compared with the SD treatments (Table 3). In general, there were no main effects of temperature on organ dry weight, except for old cane dry weight, which was greater at $21^{\circ} \mathrm{C}$ compared with $28^{\circ} \mathrm{C}$ (9.1 vs. $6.4 \mathrm{~g}$, respectively, $\left.P=0.04\right)$. Photoperiod duration also had little effect on organ dry weight, with the exception of new cane dry weight which was greater at the 8-week compared with the 4-week photoperiod duration (1.9 vs. $1.2 \mathrm{~g}$, respectively, $P=0.04)$. There were no significant differences in root dry weight among treatments (Tables 3 and 4 ). There were also no significant interactions among photoperiod, temperature, or photoperiod duration for dry weight of any organ; however, mean organ dry weights for all factors are shown in Table 4 for clarity.

There was no consistent treatment effect on leaf, cane, root, or whole-plant soluble sugars (data not shown). Starch concentration was significantly greater in the 8-week compared with the 4-week photoperiod duration for all organs (Table 5). There were no main effects of photoperiod or temperature on starch concentration in these organs. There was, however, a significant interaction between temperature and photoperiod duration on old cane and wholeplant starch concentration (Table 5). Starch concentration in old canes was greatest in the 8 -week photoperiod duration at $21{ }^{\circ} \mathrm{C}$ and lowest in the 4-week photoperiod duration at both 21 and $28^{\circ} \mathrm{C}$. The differences in old cane starch concentration were reflected in whole-plant starch concentration.

\section{Discussion}

Flower bud initiation in southern highbush blueberry has previously been shown to occur under SD (8-h) photoperiods, while long-day (16-h) and SD-NI (8-h + 1-h night interrupt in the middle of the dark period) photoperiods inhibit flower bud initiation (Spann et al., 2003). Temperature has a profound effect on photoperiodic induction of flower buds in blueberry, as it does in many horticultural crops (Pettersen, 1972; Langhans and Miller, 1960; Larson and Langhans, 1963). In the present experiment, $28^{\circ} \mathrm{C}$ decreased flower bud number compared with $21^{\circ} \mathrm{C}$ under

Table 3. Photoperiod effects on organ dry weight of 'Misty' southern highbush blueberry.

\begin{tabular}{lcccc}
\hline & \multicolumn{4}{c}{ Dry wt $(\mathrm{g})$} \\
\cline { 2 - 5 } Photoperiod & Leaves & Old canes & New canes & Root \\
\hline SD & 4.2 & 6.3 & 1.1 & 9.8 \\
SD-NI & $7.2^{* *}$ & $9.2^{*}$ & $2.0^{* *}$ & 21.9 \\
\hline
\end{tabular}

${ }^{2} \mathrm{SD}=$ short-day $(8-\mathrm{h})$ photoperiod; SD-NI $=$ short-day $(8-\mathrm{h})+1$-h night interrupt in the middle of the dark cycle. $P P F$ averaged $530 \mu \mathrm{mol} \cdot \mathrm{m}^{-2} \cdot \mathrm{s}^{-1}$ during the day for both photoperiods and $114 \mu \mathrm{mol} \cdot \mathrm{m}^{-2} \cdot \mathrm{s}^{-1}$ during the night interrupt.

***:Significant difference at $P<0.05$ or 0.01 , respectively, by $t$ test. 
Table 4. Photoperiod, temperature, and photoperiod duration effects on organ and whole-plant dry weight of 'Misty' southern highbush blueberry $(n=4)$.

\begin{tabular}{|c|c|c|c|c|c|c|c|c|}
\hline \multirow[b]{4}{*}{ Organ } & \multicolumn{8}{|c|}{ Dry wt $(\mathrm{g})$} \\
\hline & \multicolumn{4}{|c|}{$\mathrm{SD}^{\mathrm{z}}$} & \multicolumn{4}{|c|}{ SD-NI } \\
\hline & \multicolumn{2}{|c|}{$21^{\circ} \mathrm{C}$} & \multicolumn{2}{|c|}{$28^{\circ} \mathrm{C}$} & \multicolumn{2}{|c|}{$21^{\circ} \mathrm{C}$} & \multicolumn{2}{|c|}{$28^{\circ} \mathrm{C}$} \\
\hline & $4 y$ & 8 & 4 & 8 & 4 & 8 & 4 & 8 \\
\hline Root & $8.3 \mathrm{a}^{\mathrm{X}}$ & $11.2 \mathrm{a}$ & $10.3 \mathrm{a}$ & $9.2 \mathrm{a}$ & $14.9 \mathrm{a}$ & $11.2 \mathrm{a}$ & $13.1 \mathrm{a}$ & $9.7 \mathrm{a}$ \\
\hline Leaf & $4.5 \mathrm{cde}$ & 5.6 bcde & $3.6 \mathrm{de}$ & $3.0 \mathrm{e}$ & $6.2 \mathrm{abc}$ & $8.2 \mathrm{ab}$ & $6.0 \mathrm{abcd}$ & $8.4 \mathrm{a}$ \\
\hline Old cane & $5.5 \mathrm{~b}$ & $9.8 \mathrm{ab}$ & $5.4 \mathrm{~b}$ & $5.6 \mathrm{~b}$ & $9.6 \mathrm{ab}$ & $11.6 \mathrm{a}$ & $6.8 \mathrm{ab}$ & $8.7 \mathrm{ab}$ \\
\hline New cane & $0.9 \mathrm{~b}$ & $1.7 \mathrm{ab}$ & $1.1 \mathrm{~b}$ & $0.7 \mathrm{~b}$ & $1.1 \mathrm{~b}$ & $2.5 \mathrm{a}$ & $1.7 \mathrm{ab}$ & $2.7 \mathrm{a}$ \\
\hline Total plant & $19.2 \mathrm{ab}$ & $29.1 \mathrm{ab}$ & $20.5 \mathrm{ab}$ & $18.5 \mathrm{~b}$ & $31.7 \mathrm{ab}$ & $33.5 \mathrm{a}$ & $27.5 \mathrm{ab}$ & $29.5 \mathrm{ab}$ \\
\hline
\end{tabular}

${ }^{2} \mathrm{SD}=$ short-day $(8-\mathrm{h})$ photoperiod; SD-NI $=$ short-day $(8-\mathrm{h})+1$-h night interrupt in the middle of the dark cycle. $P P F$ averaged $530 \mu \mathrm{mol} \cdot \mathrm{m}^{-2} \cdot \mathrm{s}^{-1}$ during the day for both photoperiods and $114 \mu \mathrm{mol} \cdot \mathrm{m}^{-2} \cdot \mathrm{s}^{-1}$ during the night interrupt.

y 4 = 4-week photoperiod duration; $8=8$-week photoperiod duration.

${ }^{x}$ Mean separation within rows by Duncan's multiple range test, $P<0.05$.

Table 5. Photoperiod, temperature, and photoperiod duration effects on organ and whole-plant starch concentration of 'Misty' southern highbush blueberry $(n=4)$.

\begin{tabular}{|c|c|c|c|c|c|c|c|c|}
\hline \multirow[b]{4}{*}{ Organ } & \multicolumn{8}{|c|}{ Starch concn (mg glu equivalents/g dry wt) } \\
\hline & \multicolumn{4}{|c|}{$\mathrm{SD}^{\mathrm{z}}$} & \multicolumn{4}{|c|}{ SD-NI } \\
\hline & \multicolumn{2}{|c|}{$21^{\circ} \mathrm{C}$} & \multicolumn{2}{|c|}{$28^{\circ} \mathrm{C}$} & \multicolumn{2}{|c|}{$21^{\circ} \mathrm{C}$} & \multicolumn{2}{|c|}{$28^{\circ} \mathrm{C}$} \\
\hline & $4 \mathrm{y}$ & 8 & 4 & 8 & 4 & 8 & 4 & 8 \\
\hline Root & $0.8 \mathrm{c}^{\mathrm{x}}$ & $22.9 \mathrm{ab}$ & $1.2 \mathrm{c}$ & $14.7 \mathrm{~b}$ & $0.8 \mathrm{c}$ & $24.9 \mathrm{a}$ & $1.6 \mathrm{c}$ & $28.2 \mathrm{a}$ \\
\hline Leaf & $1.0 \mathrm{~b}$ & $16.0 \mathrm{a}$ & $1.3 \mathrm{~b}$ & $23.9 \mathrm{a}$ & $1.9 \mathrm{~b}$ & $26.5 \mathrm{a}$ & $0.6 \mathrm{~b}$ & $26.8 \mathrm{a}$ \\
\hline Old cane & $2.4 \mathrm{c}$ & $75.3 \mathrm{a}$ & $1.2 \mathrm{c}$ & $33.3 \mathrm{~b}$ & $1.4 \mathrm{c}$ & $67.3 \mathrm{a}$ & $0.6 \mathrm{c}$ & $23.3 \mathrm{~b}$ \\
\hline New cane & $0.8 \mathrm{c}$ & $26.0 \mathrm{a}$ & $0.7 \mathrm{c}$ & $23.8 \mathrm{a}$ & $0.9 \mathrm{bc}$ & $25.2 \mathrm{a}$ & $0.7 \mathrm{c}$ & $15.4 \mathrm{ab}$ \\
\hline Total plant & $1.4 \mathrm{c}$ & $41.6 \mathrm{a}$ & $1.2 \mathrm{c}$ & $22.9 \mathrm{~b}$ & $1.2 \mathrm{c}$ & $38.5 \mathrm{a}$ & $1.2 \mathrm{c}$ & $27.3 \mathrm{~b}$ \\
\hline
\end{tabular}

${ }^{{ }_{\mathrm{Z}} \mathrm{SD}}=$ short-day $(8-\mathrm{h})$ photoperiod; SD-NI $=$ short-day $(8-\mathrm{h})+1$-h night interrupt in the middle of the dark cycle. $P P F$ averaged $530 \mu \mathrm{mol} \cdot \mathrm{m}^{-2} \cdot \mathrm{s}^{-1}$ during the day for both photoperiods and $114 \mu \mathrm{mol} \cdot \mathrm{m}^{-2} \cdot \mathrm{s}^{-1}$ during the night interrupt.

y 4 = 4-week photoperiod duration; $8=8$-week photoperiod duration.

xMean separation within rows by Duncan's multiple range test, $P<0.05$.

inductive SD photoperiods. This high temperature reduction in flower bud number in blueberry is similar to what has been reported for strawberry (Darrow, 1936; Hartmann, 1947; Heide, 1977) and bilberry (Vaccinium myrtillus L.) (Selas, 2000). On the other hand, temperatures as low as $21^{\circ} \mathrm{C}$ could not overcome the noninductive SD-NI photoperiods.

Photoperiod duration did not affect flower bud number in SD plants grown at $21^{\circ} \mathrm{C}$. In plants grown at $28^{\circ} \mathrm{C}$, however, flower bud number increased at the 8-week compared with the 4-week photoperiod duration. This agrees with work by Phatak and Austin (1990) who reported an increase in flower bud number in rabbiteye blueberry after 6 weeks compared with 4 weeks of inductive SD photoperiods at $27^{\circ} \mathrm{C}$.

Although flower bud number was not affected by photoperiod duration in plants exposed to $21{ }^{\circ} \mathrm{C}$, the buds formed under 4-week durations were visibly smaller than those under 8-week durations. Additionally, budbreak of flowers formed after 4 weeks of SDs was delayed and reduced compared with budbreak in plants exposed to 8 weeks of SDs. This suggests that the flower buds produced during the 4-week photoperiod duration were not fully differentiated before being moved to post-treatment conditions conducive to bloom. Hall and Ludwig (1961) found that lowbush blueberry exposed to $<5$ weeks of conducive SD photoperiods produced inflorescences with elongated internodes and enlarged bracts, suggesting incomplete differentiation. However, abnormal inflorescence formation was not observed in the current experiment. Although some flower buds did form under the SD-28-8 treatment in the present experiment, these buds either remained in a dormant-like state (i.e. no swelling or enlargement was observed) or abscised. It is possible that these buds were not fully differentiated and that longer exposure to inductive photoperiods at high temperatures was required. This is the situation in strawberry, where the number of required inductive cycles increases as temperature increases (Ito and Saito, 1962; Sonsteby, 1997). High temperatures have also been shown to impair development or cause abortion of initiated flower buds in other woody plants (Hield et al., 1966; King, 1998; Moss, 1969). Although flower bud number may be indicative of flower bud initiation, it cannot be used to assess differentiation. In the present experiment, high temperature appeared to delay or impair development of initiated flower buds, resulting in failure to open.

The greater total cane length and dry weight in the SD-NI compared with the SD treatment plants at the end of the treatment period supports earlier work (Spann, 2001) and suggests that flower buds may have an inhibitory effect on vegetative growth. It could be argued that flower buds and vegetative growth are competing sinks (Darnell and Birkhold, 1996) and reduced growth was a result of carbohydrate limitation. Alternatively, the apical flower buds may impose paradormancy (i.e., apical dominance) on the more basal vegetative buds, as has been observed in strawberry (Heide, 1977). After exposure to conditions that stimulated floral budbreak in strawberry, vegetative bud break and growth also occurred. Since developing strawberry fruit are a stronger sink than flowers (Darnell and Martin, 1988), this suggests that sink competition was not the primary factor responsible for inhibition of vegetative bud growth. In the current experiment, there was an increase in vegetative growth in $\mathrm{SD}$ treated plants $\left(\right.$ at $21^{\circ} \mathrm{C}$ ) between weeks 4 and 6 of the post-treatment observation period, which coincided with bloom. Additionally, there was no significant difference in 
net $\mathrm{CO}_{2}$ assimilation rates or organ carbohydrate concentrations in SD-NI vs. SD treated plants. This suggests the inhibition of vegetative bud growth in blueberry exposed to SD compared with SD-NI conditions was more likely a paradormant effect rather than a carbohydrate limitation due to sink competition.

Darnell and Birkhold (1996) reported that fall flower bud development and vegetative canopy establishment in the spring reduced root starch concentrations to near zero in rabbiteye blueberry. In the present experiment, the low starch concentration found in all tissues at 4 weeks into the photoperiod/temperature treatments may have been due to the sink demand of developing vegetative growth, which likely depleted the carbohydrate reserves. As the vegetative canopy developed and whole-plant $\mathrm{C}$ fixation increased, starch concentrations in tissues increased. However, after 8 weeks, the increase in starch in old canes and whole plants was less at high versus low temperatures, possibly due to increased respiration rates at higher temperatures (James, 1953; Opik, 1980). Temperature did not influence starch concentration in roots, leaves, or new canes. It is unclear why starch concentration of leaves and new canes was unaffected by temperature, as respiration of these tissues also would be expected to increase at higher temperatures. Root respiration, and thus root starch concentration, may have been unaffected by temperature due to an insulating effect by the pine bark media, although no root temperature data were recorded.

There was no correlation between carbohydrate concentrations and flower bud initiation under SD versus SD-NI conditions. This, combined with the nearly complete inhibition of flower bud initiation in the SD-NI treatment plants, supports the conclusion that flower bud initiation in blueberry is primarily a phytochrome- mediated and not a carbohydrate-mediated response (Spann et al., 2003). However, within SD conditions, decreased carbohydrate concentration was correlated with decreased flower bud initiation at high temperature, suggesting that carbohydrate may become limiting under certain conditions.

Flower bud initiation in 'Misty' southern highbush blueberry is adversely affected by high temperatures. In the present work, such temperatures not only reduced the number of flower buds initiated, but caused initiated buds to become nonviable. Duration of photoperiodic inductive conditions delayed and reduced bloom, apparently by delaying or impairing floral differentiation. The increase in flower bud initiation observed under the SD, $21^{\circ} \mathrm{C}$ versus other treatments was not correlated with net $\mathrm{CO}_{2}$ assimilation rate, detectable increases in carbohydrate concentrations, or differences in carbohydrate partitioning. This indicates that flower bud initiation in blueberry is a phytochrome-mediated SD response that can be negated by high temperature. Whether temperatures $<21{ }^{\circ} \mathrm{C}$ can override the SD requirement for flower bud initiation in blueberry, as it does in strawberry, is unknown.

\section{Literature Cited}

Aalders, L.E. and IV. Hall. 1964. A comparison of flower-bud development in the lowbush blueberry, Vaccinium angustifolium Ait. under greenhouse and field conditions. Proc. Amer. Soc. Hort. Sci. 85:281-284.

Bernier, G., A. Havelange, C. Houssa, A. Petitjean, and P. Lejeune. 1993. Physiological signals that induce flowering. Plant Cell 5:1147-1155.

Bodson, M. 1977. Changes in the carbohydrate content of the leaf and the apical bud of Sinapsis during transition to flowering. Planta 135:19-23.

Buysse,J.and R. Merckx. 1993.Animproved colorimetric method to quantify sugar content of plant tissue. J. Expt. Bot. 44:1627-1629.

Chaplin, M.F. and J.F. Kennedy. 1994. Carbohydrate analysis: A practical approach. $2^{\text {nd }}$ ed. IRL Press, Oxford.
Darnell, R.L. 1991. Photoperiod, carbon partitioning, and reproductive development in rabbiteye blueberry. J. Amer. Soc. Hort. Sci. 116:856-860.

Darnell, R.L. and K.B. Birkhold. 1996. Carbohydrate contribution to fruit development in two phenologically distinct rabbiteye blueberry cultivars. J. Amer. Soc. Hort. Sci. 121:1132-1136.

Darnell, R.L. and G.C. Martin. 1988. Role of assimilate translocation and carbohydrate accumulation in fruit set of strawberry. J. Amer. Soc. Hort. Sci. 113:114-118.

Darrow, G.M. 1936. Interrelation of temperature and photoperiod in the production of fruit-buds and runners in the strawberry. Proc. Amer. Soc. Hort. Sci. 34:360-363.

Dubois, M., K.A. Gilles, J.K. Hamilton, P.A. Rebers, and F. Smith. 1956. Colorimetric method for determination of sugars and related substances. Anal. Chem. 28:350-356.

Hall, I.V., F.R. Forsyth, and R.J. Newbery. 1970. Effect of temperature on flower bud and leaf anthocyanin formation in the lowbush blueberry. HortScience 5:272-273.

Hall, I.V. and R.A. Ludwig. 1961. The effects of photoperiod, temperature, and light intensity on the growth of the lowbush blueberry (Vaccinium angustifolium Ait.). Can. J. Bot. 39:1733-1739.

Hartmann, H.T. 1947. Some effects of temperature and photoperiod on flower formation and runner production in the strawberry. Plant Physiol. 22:407-420.

Heide, O.M. 1977. Photoperiod and temperature interactions in growth and flowering of strawberry. Physiol. Plant. 40:21-26.

Hield, H.Z., C.W. Coggins, Jr., and L.N. Lewis. 1966. Temperature influence on flowering of grapefruit seedlings. Proc. Amer. Soc. Hort. Sci. 89:175-181.

Ito, H. and T. Saito. 1962. Studies on the flower formation in the strawberry plants I. Effects of temperature and photoperiod on the flower formation. Tohoku J. Agr. Res. 13:191-203.

James, W.O. 1953. Plant respiration. Clarendon Press, Oxford.

King, R.W. 1998. Dual control of flower initiation and development by temperature and photoperiod in Hardenbergia violacea. Austral. J. Bot. 46:65-74.

Langhans, R.W. and R.O. Miller. 1960. Influence of daylength, temperature and number of short days on the flowering of poinsettia (Euphorbia pulcherrima). Proc. Amer. Soc. Hort. Sci. 75:753-760.

Larson, R.A. and R.W. Langhans. 1963. The influences of temperature on flower bud initiation in poinsettia (Euphorbia pulcherrima Willd.). Proc. Amer. Soc. Hort. Sci. 82:552-556.

Moss, G.I. 1969. Influence of temperature and photoperiod on flower induction and inflorescence development in sweet orange (Citrus sinensis L. Osbeck). J. Hort. Sci. 44:311-320.

Opik, H. 1980. The respiration of higher plants. Edward Arnold Ltd., London.

Pettersen, H. 1972. The effect of temperature and daylength on shoot growth and bud formation in azaleas. J. Amer. Soc. Hort. Sci. 97:17-23.

Phatak, S.C. and M.E. Austin. 1990. The effect of photoperiod on the growth and flowering of two rabbiteye blueberry cultivars. App. Agr. Res. 5:350-352.

Rees,A.R. 1987.Environmental and genetic regulation of photoperiodism-A review, p. 187-202. In: J.G. Atherton (ed.). Manipulation of flowering. Butterworths, Boston.

Selas, V. 2000. Seed production of a masting dwarf shrub, Vaccinium myrtillus, in relation to previous reproduction and weather. Can. J. Bot. 78:423-429.

Sonsteby,A. 1997. Short-day period and temperature interactions on growth and flowering of strawberry. Acta Hort. 439:609-616.

Spann, T.M. 2001. Environmental influences on flower bud initiation in Vaccinium species. MS thesis. Univ. Fla., Gainesville.

Spann, T.M., J.G. Williamson, and R.L. Darnell. 2003. Photoperiodic effects on vegetative and reproductive growth of Vaccinium darrowi and $V$. corymbosum interspecific hybrids. HortScience 38:192-195.

Vince-Prue, D. 1986. The duration of light and photoperiodic responses, p. 269-305.In: R.E. Kendrick and G.H.M. Kronenberg(eds.). Photomorphogenesis in plants. Martinus Nijhoff/Dr. W. Junk Publishers, Dordrecht. 